\title{
The Determinants and Forecasting of Petroleum Supply in Pakistan
}

\author{
FAZLE WAHID \\ Department of Economics, Islamia College Peshawar. \\ Email: eco_wahid@yahoo.com \\ HAMID ULLAH \\ Department of Management Sciences, Islamia College Peshawar. \\ Email: hamidullah@icp.edu.pk \\ SHABANA PARVEEN \\ Department of Economics, Hazara University Mansehra. \\ Email: shabana_economist@yahoo.com \\ BIBI AISHA SADIQA \\ Department of Economics, Hazara University Mansehra. \\ Email: agrieco24@yahoo.com
}

\begin{abstract}
The main objective of the study is to find out the determinants of petroleum supply and also to forecast the future supply of petroleum in Pakistan for the period of 1972-2018.Johenson Cointegration technique is employed to get the required objective. It is assumed that GFCF, FDI, FOP and Technology are the main determinants of petroleum supply in the country based on past literature. Sign of the coefficient of the variables are in line with theory. The study concludes that GFCF, FOP and Technology are statistically significant determinants of total petroleum supply in Pakistan. The study forecasted the petroleum supply in Pakistan from 2019 to 2030 by using ARIMA model. The results show that average forecast value of total petroleum 11864.3 by 2030. According to the ARIMA forecasted results, there is increasing trend in the supply petroleum products. The finding of the study shows that the price of petroleum and technology has positive impact on total petroleum supply. The results showed that price elasticity of petroleum supply is inelastic. The results of forecasted values showed the increasing trend in supply of petroleum.
\end{abstract}

Keywords: Petroleum Supply, Determinants and Forecasting, Time Series, Pakistan.

\section{Introduction}

Persistent and adequate energy supply is vital for growth and development of a country. Modern research considers that along with other factors energy have significant role in economic uplifting of developing economies, because energy demand and economic growth have close fitting. Last two decades Pakistan faces sever energy crises, which have raise import bill of petroleum but also directly and indirectly affected almost all sectors of economy. To fix mismatch between energy demand and supply, a lot of projects were initiated to the supply side from 2013 to 2018. While the additional capacity slightly eases the bottlenecks at supply side of energy, hitherto the transmission and distribution side weakness has hindered the persistent supply of energy to the economy (IEA, 2005 and Economic Survey of Pakistan 2018). The discovery and explorations of various energy sources locally may provide prospects of employment uplifting of economic condition of masses and meet the energy requirement of different sectors of 
economy. The explored resources of energy may reduce the import bill of petroleum, gas, coal and chemicals etc. (Asif, 2011 and Pelesai, 2013).

In overall energy mix, Pakistan dependence on petroleum oil is 43.5 percent in 1998 and 2001, however in 2018 the dependence on oil reduced to 31.2 percent have good sign in the shape of fewer burdens on treasury of Pakistan. The share of hydro was 13.1 percent in 1998, which remains 7.7 percent in 2018, it indicates shortsightedness of policy and incompetence of government to launch timely capital intensive projects in concerned field. The share of natural gas in 2006 was 50.4 percent and decline to 34.6 percent in 2018. The share of gas decline due to decrease its reserves and along with this decrease occur in consumption of gas in transport sector and also initiation of LNG since 2015. Coal was remaining in single digit percentage in last two decades, while its consumption in 2018 has risen up to 12.7 percent. Part of renewable energy was 0.3 percent in 2015 , which rose by 1.1 percent in 2018. Share of nuclear energy increased by 2.7 percent in 2018 as compared to 0.2 percent in 1997.such variation in share of each energy components in the energy mix of the country has been used effectively for formulation and implementation of energy plan (Economic Survey of Pakistan 2018).

Determining and precise forecasting of petroleum supply is highly significant for the longer development of a country. While mend of petroleum supply shaping is made by the researchers, institutions and government throughout the world, it will offer assistance to handle vitality emergencies successfully. Especially for nation Pakistan, precise determination of petroleum supply is of more importance. The diversion in supply and demand is persistently on widening with the passage of time (IPP, 2008).

It is obvious that the need for energy is increasing over time, therefore it is necessary to make needful action and make suitable policies regarding the demand and supply of energy source. The government has the responsibility to make sure smooth supply to satisfy the need of the day. For future policy making it is prior to know the forecast of energy. The country has the potential regarding different sources of hydro and coal potential etc. Using circulated assets in indigenous limit while satisfying the needs of unstable financial sine bends of development and advancement, require a point of view of feasible vitality utility with flexibility and versatile limit at center and on the loose. The Ministry of Energy is entrusted with development in the limit of conveying vitality, requiring supporting extension in the transmission foundation for clearing of the force. The administration has empowered neighborhood and outside interest in the age, transmission and appropriation gracefully chains of the conveyance of administration to fuel the economy.

\section{Literature Review}

Pelesai (2013) compared the electricity demand and supply in Nigeria. The reduced form model and VECM approach were used in the study. The results of the study illustrated that both price of electricity and income of the consumers has elastic demand, as any increment in electricity price will reduced revenue generation for Power Company. Further the study found a gap between electricity demand and supply due to deficiencies in electricity production. Current study also demonstrated that Nigeria power sector associated with diseconomies of scale as outcome inadequacy occur to innovation in order to enhance power generation at lowest cost. The study suggested that government and policy makers must take effective measures to overcome the problems of inability and lack of innovation to minimize wastage of resources and boost electricity supply to insure not only economic growth but to generate handsome revenue for government for improvement in infrastructure to achieve overall economic development.

Ubi (2012) the study recognized that lack of electricity supply has main obstacle to industrial and economic development in Nigeria. The government has started a numbers of projects to increase electricity supply but has failed to achieve the targets, because due to inefficiency of policy makers to acknowledge the proper determinants of electricity supply for policy implementation. 
This study used different econometrics method of co integration, stationary test and ordinary least square for analysis of time series data from 1970-2009. The regression model states that electricity supply is depended on government funding, price per Megawatt, rainfall, technology and quantity of power loss. The OLS results illustrated that power loss; government funding and technology were key and statistically significant determinants of electricity supply. While electricity price has positive but statistically insignificant effect on electricity supply at $5 \%$ level of significance. The study suggests that the government should insert more funds to introduce modern technology to complete the existing projects and initiated new projects in order to increase electricity supply.

Kebede et al., (2010) analyzed cross sectional time series data from twenty countries of Sub Saharan Africa. The outcomes demonstrated that there are negative yet inelastic relationship exists between oil request and oil costs while GDP, populace and agribusiness development have constructive outcome on oil utilization. Further value, GDP and horticultural extension have measurably huge impact on oil utilization. The examination demonstrated the territorial contrasts in GDP development rate, populace development and vitality request. Finally study suggested that the nations ought to expand and present current innovation in all divisions of vitality so as to upgrade cause increase in GDP.

Naryan and Wong (2009) estimated relationship between oil consumption and independent variables like oil price and GDP per capita. According to Granger causality test the results showed that the study variables were co integrated. The study calculated long run price and income elasticity of oil demand. From results it has found that oil price has negative and statistically insignificant effect on oil consumption, while income has statistically significant and positive effect on oil consumption in Australia.

Okafar (2008) studied that the power crisis has vast effect on industrial infrastructure of Nigeria. Technological infrastructure has important for industrialization, economic growth and technological progress. Technological infrastructure consists of energy, power supply, transport and communication etc but this study relay mainly on power supply. Further this study examined that the government allocate massive fund to power sector in 1999 to 2007 was produce almost 3000 MW electricity despite the requirement of $10000 \mathrm{MW}$. This scarcity of electricity supply has severely affect industrial sector of Nigeria. The study recommended that on urgent basis renovate the overall power sector of Nigeria to insure the industrial and economic development in the country.

Sambo (2008) has examined and counterpart energy supply with demand in Nigeria. The expected electricity demand was calculated. The key determinants of energy demand were economic growth, population and technology. Out of which GDP and structure of economy were dominant factors. The electricity supply stratagem depends on the expected electricity demand as a factor. The projected $484.62 \mathrm{~b}$ dollars of total investment required to meet the energy demand for buoyant growth. The government might not afford that much height of funding separately, along with Govt., private sectors and foreign direct investment have to engage. Further the domestic resources of energy should be utilized in order to equate energy supply with demand on retinue basis in the country.

Mohamed et al (2005) used Harvey and logistic models to forecast electricity consumption. The Harvey model forecasted high electricity consumption then the Logistic model, while Harvey Logistic model provided forecasts in between the other two models. The Harvey model was best to forecast domestic sector electricity consumption, while Logistic model gave best results to forecast non domestic electricity consumption. But overall the Harvey model was best to forecast the total electricity consumption. The forecast obtained from all three models were found more accurate then national forecast. At last the study concluded that in New Zealand the total electricity consumption including domestic and non-domestic sectors will increasing more in future.

Lledare (1995) has developed and calculate supply model of natural gas in West Virginia using data on 18000 new drilled wells from 1997 to 1987 . The study found that sensitivity of gross reserve and drilling 
attempt with in same individual geological series to the expected per well head price, exhaustion of resource, taxes and costs. The study suggests effective policies in shape of incentives and relaxation to increase supply of natural gas.

Furtadoa and Suslickb (1993) forecasted petroleum demand in Brazil. Results of the study showed that GDP was key determinant of petroleum consumption and petroleum price have insignificant effect on petroleum consumption. The study assessed that forecasting models showed accurate results and use of petroleum share in energy mix has increased since 1973. The study suggests that in future petroleum consumption have important role in GDP growth of Brazil.

\section{Theoretical Framework and Methodology}

For analysis the determinants of supply of petroleum, the basic theory of supply is in support of theoretical background of the present study. Here supply of energy means output offered for sale at given price. It is obvious that the suppliers offer more for sale at higher price and low at lower price and other determinants like cost of production, price of substitute, technology, weather condition and stock of capital etc have effect on petroleum supply. Due to unusualness in energy market in Pakistan the stated law of supply may not inevitably hold in true sense, because usually components of energy supplied by government and enjoy monopoly power.

\section{Data Collection and Sources}

In this investigation, times arrangement auxiliary yearly information on various factors for exact examination for the period extending from 1970 to 2018 has been utilized. The information required for the investigation is acquired from different sources. The information for all out oil gracefully, complete oil is taken from Economic Survey of Pakistan different issues. Information of GFCF and FDI are sources from The Statistical, Economic and Social Research and Training Center for Islamic Countries (SESRIC). Technology variable is taken as proxy by time trended. The data on final oil price as an index is constructed. As for as the price of oil is concerned; it defer from sector to sector and component to component. For instance, the oil has different components like motor spirit, high speed diesel, light speed diesel, kerosene, and furnace oil with their respective prices. Likewise, the costs change across segments and across purchasers. Vitality year books report this costs information in very subtleties. To build total cost lists for oil we utilized the device of weighted normal list approach. The loads could be built by utilizing the relative utilization share and the time base. Time weight implies that if a cost is viable for thirty days, for instance, it will get twice as much weight when contrasted with value which is viable for fifteen days.

\section{Selection of the Variables}

Petroleum Supply: Total petroleum supply in all sectors of Pakistan is taken as dependent variable. In this study total supply of petroleum is represented by "TPS".

Prices of Petroleum: Price of petroleum is significant determinants of petroleum supply. Other things remaining same, supply and price have positive relationship as an increase in price occur increase in supply of petroleum and vice versa. In Pakistan prices of energy set administratively, that ultimately help in enhancing revenue generation, it further invests in energy oriented technology sectors which will increase energy supply. A Price of petroleum is represented by "FOP".

Gross Domestic Investment: It is proxy by Gross Fixed Capital Formation (GFCF), because the data of GDI is not available for most of the developing countries. GFCF is the combination of the total value of fixed valuable by household, firms and government. Gross fixed capital formation has positive impact on petroleum supply. 
Technology: It is one of the essential factors of energy supply. Advancement in technology in favors of energy sectors will boost up energy supply. Introduction of suitable technology in energy sectors will insure specialization and division of labor and ultimate enhance energy supply at lower cost. Technology is denoted by @ trend.

Foreign Direct Investment: "FDI" is an investment of a company of a country in another country. FDI has positive impact on energy supply especially on petroleum supply in the form of exploration and utilization of reserves.

\section{The Model}

The designs of the models of energy supply for the study are consistent with the literature of Isola (2007), IEA (2002), Lledare (1995), Lwayemi (2008), Ubi (2012). It provides foundation for identification of the determinants of supply of energy components of Pakistan.

LnTPS $=\mathrm{b}_{0}+\mathrm{b}_{1} \operatorname{lnGFCF}+\mathrm{b}_{2}$ LnFDI $+\mathrm{b}_{3}$ LnFOP $+\mathrm{b}_{4}$ Ln@ $@$ TREND $+\mathrm{Ut}$

Where

\begin{tabular}{|l|l|}
\hline TPS $=$ Total Petroleum Oil Supply (000 tons) & GFCF $=$ Gross Fixed Capital Formation (Rs.bn) \\
\hline FDI $=$ Foreign Direct Investment (Rs.bn) & FOP $=$ Final Oil Price \\
\hline @ TREND = Technology & \\
\hline
\end{tabular}

Also $b_{0}$ is the intercept and $b_{i}$ coefficients while

$\mathrm{U}_{\mathrm{t}}$ is Error term which includes the effect of all those variables which are not included in the model.

\section{Results and Discussions}

The study has used Augmented Dickey Fuller test for stationarity of data. The results of ADF test are given in table 1. According to the t-statistics value of ADF test for all the following variables (LGFCF LTPS LFDI LFOP) are statistically significant at first difference. Thus the variables turn out to be stationary at first difference or order 1(1).

Table 1: Unit Root Test Results

\begin{tabular}{|c|c|c|c|c|c|}
\hline Variables & \multicolumn{2}{|l|}{ Level } & \multicolumn{2}{l|}{ First difference } & Conclusion \\
\hline & $\begin{array}{c}\text { Statistic } \\
\text { value }\end{array}$ & $\begin{array}{c}\text { Critical } \\
\text { value at 5\% }\end{array}$ & $\begin{array}{c}\text { Statistic } \\
\text { value }\end{array}$ & $\begin{array}{c}\text { Critical value } \\
\text { at 5\% }\end{array}$ & \\
\hline LFOP & .4 & -3.09 & $-4.37^{*}$ & -3.19 & $1(1)$ \\
\hline LTPS & -.9 & -3.12 & $-4.32^{*}$ & -3.26 & $1(1)$ \\
\hline LFDI & -1.82 & -3.20 & $-6.79^{*}$ & -3.16 & $1(1)$ \\
\hline LGFCF & -1.67 & -3.08 & $-5.13^{*}$ & -3.33 & $1(1)$ \\
\hline
\end{tabular}

*represented the acceptance of alternative Hypothesis

\section{Cointegration Test for Total Petroleum Supply}

The results of Johansen co-integration technique are given in table 2. The estimations of Maximum Eigen statistic and Trace statistic are utilized to research the co-coordination. The worth examination among the follow insights, the most extreme Eigen and the basic qualities (at 5 percent level of significance) are tried. The examination advocated that the estimation of follow measurements, the most extreme Eigen is more noteworthy than basic qualities. Consequently invalid theory is dismissed and option of presence of co reconciliation is acknowledged methods, there is co-coordination. The follow insights affirm one co 
incorporating vectors and the most extreme Eigen values likewise affirm one existence of long run relationship at 5 percent are noteworthiness level.

Thus the results confirm the existence of long run relationship between total petroleum supply and GFCF, TEC, FDI and FOP.

Table 2: Results of Johansen Co Integration Test for Total Petroleum Supply

\begin{tabular}{|c|c|c|c|c|c|}
\hline $\mathbf{H}_{\mathbf{0}}$ & $\mathbf{H}_{\mathbf{1}}$ & $\begin{array}{c}\text { Trace } \\
\text { Statistics }\end{array}$ & $\begin{array}{c}\text { Critical Value } \\
\text { At 5\% }\end{array}$ & $\begin{array}{c}\text { Max- Eigen } \\
\text { Statistics }\end{array}$ & $\begin{array}{c}\text { Critical Value } \\
\text { At 5\% }\end{array}$ \\
\hline $\mathrm{R}=0$ & $\mathrm{R} \geq 1$ & $80.30^{*}$ & 70.99 & $38.45^{*}$ & 36.77 \\
\hline $\mathrm{R} \leq 1$ & $\mathrm{R} \geq 2$ & 40.85 & 50.07 & 20.27 & 28.83 \\
\hline $\mathrm{R} \leq 2$ & $\mathrm{R} \geq 3$ & 19.52 & 30.9 & 10.05 & 23.36 \\
\hline $\mathrm{R} \leq 3$ & $\mathrm{R} \geq 4$ & 7.58 & 16.97 & 6.35 & 13.66 \\
\hline
\end{tabular}

$* \mathrm{H}_{0}$ and $\mathrm{H}_{1}$ represent Null and Alternative Hypotheses

\section{Multiple Regression Models Estimation}

This study deals in time series data hence stationarity of the data is necessary and desirable to get efficient estimates. For the purpose of stationarity we used ADF test and for the existence of long run relationship Johansen co integration technique. On the basis of the outcomes of the ADF i.e. all variables are stationary at first difference, Johnson technique is employed.

\section{Estimation of Determinants of Total Petroleum Supply}

The results from regression are given in table 3. The results confirm that all independent variables have positive effects on total petroleum supply and the relationship among variables is in line with economic theory. The following determinants of petroleum supply such as GFCF, TEC, FOP and technology are statistically significant at 5\% level of significance. Whereas the coefficient of Foreign Direct Investment (FDI) is statistically significant at 10 percent level but insignificant at 5 percent level of significance, due to the basis that little portion of FDI attracted to the field of oil exploration. Minute attraction of FDI to the field may be due to the reason of political instability, law and order situation and inefficient government policy. The coefficients show that on average one percent increase in GFCF, FDI, FOP and technology leads to 0.03 , 0.08 and 0.23 percent increase in total petroleum supply respectively.

Table 3: Regression Results of Determinants of Total Petroleum Supply

\begin{tabular}{|c|c|c|c|}
\hline \multicolumn{5}{|c|}{ Dependent variable LTPS } \\
\hline Variable & Coefficient & T-statistic & Prob. \\
\hline Constant & -0.38 & -0.17 & 0.875 \\
\hline LGFCF & 0.03 & 3.30 & 0.002 \\
\hline LFDI & 0.08 & 0.81 & 0.320 \\
\hline LFOP & 0.23 & 2.96 & 0.021 \\
\hline @TREND & 0.11 & 3.02 & 0.009 \\
\hline \multirow{2}{*}{$\mathrm{R}^{2}=0.896$} & \multicolumn{2}{|c|}{$\mathrm{Adj}^{2}=0.862$} \\
\hline \multirow{2}{*}{ F-Stat $=80.23$} & Pro(F-stat) $=0.000$ \\
\hline \multicolumn{4}{|}{ Durbin-Watson $=2.18$} \\
\hline
\end{tabular}




\section{Short Run Dynamics ECM}

After the confirmation of the existence of long run relationship then we need to know the estimated values of short run parameters and the speed of adjustment towards long run relationship.

Table-4 shows the results of ECM. In short run all explanatory variables have positive effects except GFCF has negative effects on TPS. The GFCF and TEC are statistically significant and FDI and FOP are insignificant at 5\% level. All variables are according to economic theory except of GFCF. The coefficient of error correction term is negative and has statistically significant at 5\% level, which confirms stable long run equilibrium among variables.

Table-4 shows the aftereffects of ECM. In short run every single included variable have beneficial outcomes aside from GFCF which affects negatively TPS. The GFCF and TEC are affecting significantly while the impact of FDI and FOP are not significant to TPS at 5\% level. All factors are as indicated by financial hypothesis aside from of GFCF. The coefficient of error term is negative and significant at $5 \%$ level affirms stable and unique relationship among variables.

Table 4: ECM Results for Total Petroleum Supply

\begin{tabular}{|c|c|c|c|}
\hline \multicolumn{4}{|c|}{ Dependent variable D(LTPS) } \\
\hline Variable & Coefficient & T-statistic & Prob. \\
\hline Constant & 0.006 & 0.160 & 0.874 \\
\hline $\mathrm{D}(\mathrm{LGFCF})$ & -0.331 & -2.208 & 0.037 \\
\hline D(LTEC) & 0.993 & 2.864 & 0.009 \\
\hline $\mathrm{D}(\mathrm{LFDI})$ & 0.009 & 0.341 & 0.736 \\
\hline $\mathrm{D}(\mathrm{LFOP})$ & 0.025 & 0.241 & 0.812 \\
\hline ECT06(-1) & -0.375 & -2.177 & 0.040 \\
\hline \multicolumn{2}{|c|}{$\mathrm{R}^{2}=0.62$} & \multicolumn{2}{|c|}{$\operatorname{Adj}^{2}=0.588$} \\
\hline \multicolumn{2}{|c|}{ F-Stat $=6.243$} & \multicolumn{2}{|c|}{$\operatorname{Prob}(\mathrm{F}-$ stat $)=0.028$} \\
\hline \multicolumn{4}{|c|}{ Durbin-Watson $=2.40$} \\
\hline
\end{tabular}

\section{Graphic Representation of CUSUM Tests}

From the given below plots of CUSUM and CUSUM squares are lies within the given bound at $5 \%$ levels of significance, which show the stability of parameters in the model.

\section{Total Petroleum Supply}

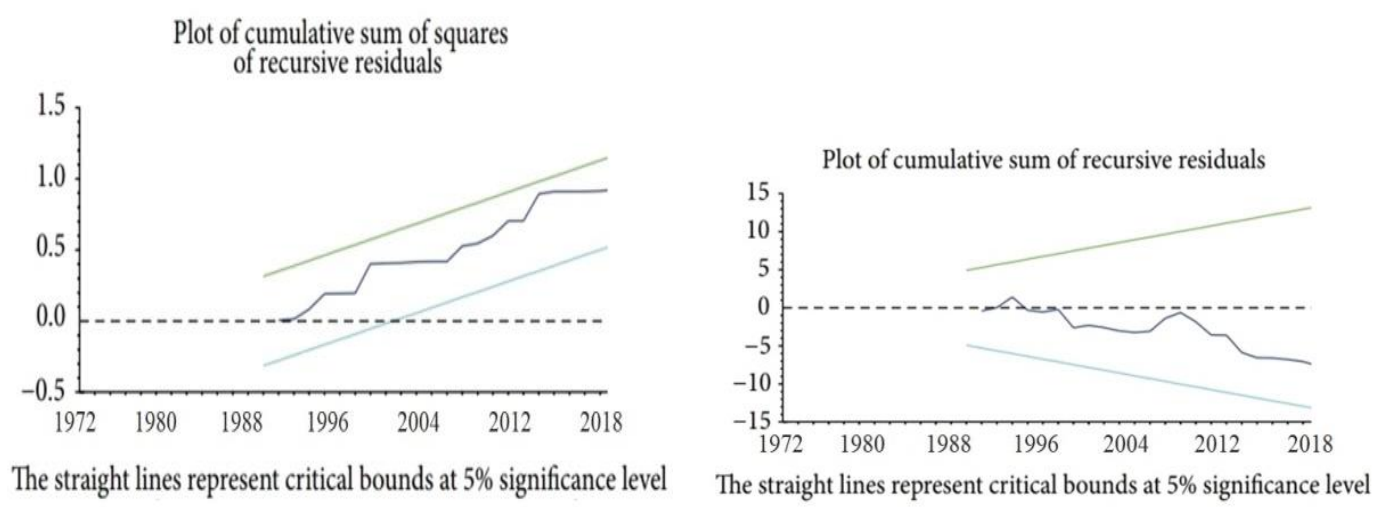




\section{Forecasts of Total Petroleum Supply}

The values of the total petroleum supply for the years 2019 to 2030 is given in the following table- 6 . The forecasted figures for the said period are estimated with the help of ARIMA. The resulted figures show average total petroleum supply for the period of 2019 to 2020 reveals an increasing trend. The result illustrates that in future there will be an increase in trends of total petroleum supply and turn out to be 11864.3 tons in 2030 .

Table 6: Forecasting of Total Petroleum Supply from 2011 to 2025

\begin{tabular}{|c|c|c|c|}
\hline $\begin{array}{c}\text { Projected } \\
\text { Years }\end{array}$ & $\begin{array}{c}\text { Forecasted } \\
\text { petroleum supply } \\
\text { (tons) }\end{array}$ & $\begin{array}{c}\text { Lower 95\% } \\
\text { confidence } \\
\text { interval }\end{array}$ & $\begin{array}{c}\text { Upper 95\% } \\
\text { confidence interval }\end{array}$ \\
\hline $\mathbf{2 0 1 9}$ & 10212.1 & 6732.4 & 13691.9 \\
\hline $\mathbf{2 0 2 0}$ & 10362.3 & 6688.8 & 14035.8 \\
\hline $\mathbf{2 0 2 1}$ & 10512.5 & 6655.1 & 14370 \\
\hline $\mathbf{2 0 2 2}$ & 10662.7 & 6629.6 & 14695.8 \\
\hline $\mathbf{2 0 2 3}$ & 10812.9 & 6611.6 & 15014.3 \\
\hline $\mathbf{2 0 2 4}$ & 10963.1 & 6600 & 15326.3 \\
\hline $\mathbf{2 0 2 5}$ & 11113.3 & 6594.2 & 15632.5 \\
\hline $\mathbf{2 0 2 6}$ & 11263.5 & 6540.725 & 15986.39 \\
\hline $\mathbf{2 0 2 7}$ & 11413.7 & 6513.692 & 16313.83 \\
\hline $\mathbf{2 0 2 8}$ & 11563.9 & 6486.658 & 16641.27 \\
\hline $\mathbf{2 0 2 9}$ & 11714.1 & 6459.625 & 16968.72 \\
\hline $\mathbf{2 0 3 0}$ & 11864.3 & 6432.592 & 17296.16 \\
\hline
\end{tabular}

\section{Conclusions and Policy Recommendations}

Following are the important findings of the study.

- From the empirical results of the study, it is obvious and obtained that data on all variables are stationary, at first difference in order and according to Johenson co-integration test results confirm existence of long run relationship amongst variables of interest .Moreover, it is found from ECM technique that Error Correction Term is negative, and statistically significant which means that in case of any shock there will be restore stable long run equilibrium for all components of petroleum supply in Pakistan on the basis of short run dynamics.

- From the estimation it is assumed that all explanatory variables i.e. GFCF, FDI, FOP and Technology have positive consequence on total petroleum supply. Sign of the coefficient of the variables are in line with theory. The study concludes that GFCF, FOP and Technology are statistically significant determinants of total petroleum supply in Pakistan.

- The study forecasted the petroleum supply in Pakistan from 2019 to 2030 by using ARIMA model. The results show that average forecast value of total petroleum 11864.3 by 2030 . According to the ARIMA forecasted results, there is increasing trend in the supply petroleum products.

The finding of the study shows that the price of petroleum and technology has positive impact on total petroleum supply. The results showed that price elasticity of petroleum supply is inelastic. The results of forecasted values showed the increasing trend in supply of petroleum.

\section{Recommendations of the Study}

This reality can't be overlooked that Pakistan is wealthy in different common assets, for example, the paths of petroleum gas, coal, oil and broadened water assets. However, in Pakistan, assets accessibility isn't an 
issue. The more significant issue is underutilization and misuse of accessible assets, uncertainty, blunder, sick arranging and no affectation to pull in FDI and MNCS to vitality area of Pakistan. Throughout the previous two decades Pakistan faces serious vitality emergencies. Increment in vitality request further manifolds the emergencies. The principle factors answerable for the expansion in emergencies is financial development, industrialization, expanded per capita vitality utilization, improve horticulture profitability, development in administrations, urbanization, modernization, expanded per capita salary and giving power to Rural zones (NBP, 2008)The results of study demonstrate that price elasticity of petroleum supply is inelastic and prevailing energy crises require economic deregulation and modification in the energy market in the form of privatization and liberalization. Due to entrance of private sector along with public ownership strong competition will start and as outcome minimize the production cost, diminish shortage and ultimate increase revenue generation. Further, economic growth will escalate and fiscal burden will decrease.

- To bridge the increasing gap between energy demand and supply as we find from forecasting of petroleum supply, it is important to sort out alternative techniques and resources. It is also essential to focus on gas and coal base electricity along with petroleum base in collaboration with private sector and public sector. Atomic energy sector also to be exploited more extensively instead of depending on costly fuel.

- In 2002 Alternative Energy Development Board (AEDB) of Pakistan set momentary objective that 700 MW windmill power will include by 2007 and long haul objective of AEDB that right around 9700 power will be included from inexhaustible sources by 2030. Another objective of AEDB to provide renewable energy to 7874 far-flung villages of Baluchistan and Sindh provinces of Pakistan. But AEDB does not seem to be successful in achievements of these targets. A comprehensive short and long term projects should be initiated to generate electricity from solar and wind through participation of private sector.

- As we know from results that FDI has positive and significant effect on energy supply. So government should attract foreign and private investments to explore new and alternative energy resources. The government should also devise attractive policies and implement them in letter and spirit to utilize available energy resources properly.

\section{References}

Asif, M., 2011. Energy Crisis in Pakistan: Origins, Challenges, and Sustainable Solution. Oxford University Press, 3-10.

Dickey, D.A., Fuller, W. A., 1979. Distribution of the Estimation for Autoregressive Time Series with Unit Root. Journal of the American Statistical Association, 74(366), 427-431.

Dickey, D.A., Fuller, W. A., 1981. Likelihood Ratio Statistics for Autoregressive Time Series with a Unit Root. Econometrica, 49(4), 1057-1072.

Economic Survey of Pakistan, 2010-11. Ministry of Finance, Government of Pakistan. Islamabad. July 2011.

Energy Year Book, 2009-10 (various issues). Ministry of Petroleum and Natural Resources, Government of Pakistan. Islamabad. 2010.

Furtadoa, A. T., Suslickb, S. B. 1993. Forecasting of Petroleum Consumption in Brazil Using the Intensity of Energy Technique. Energy Policy, 21, 958- 968.

Granger, C., Newbold, P., 1974. Spurious Regressions in Econometrics. Journal of Econometrics, 2(2), 111-120.

IEA. World Energy Outlook., 2002. International Energy Agency, Economic Analysis Division, France; 2002.

International Energy Agency (IEA) Statistics Oil Information (2009-10), http://www.iea.org/. 9, rue de la Fédération, France.

International Financial Statistics., 2009-10. Statistics Department International Monetary Fund Washington, D.C. U.S.A. 
Isola, W. A., 2007. Developments in the Nigerian Electricity Sector. A paper presented at the $50^{\text {th }}$ anniversary of the Nigerian Economic Society, September $8^{\text {th }}$, Abuja, Nigeria.

Kebede, E., Kagochi, J., Jolly, C. M., 2010. Energy Consumption and Economic Development in Sub Sahara Africa. Energy Economics, 32, 532- 537.

Lledare, O. O., 1995. Simulating the Effect of Economic and Policy Incentives on Natural Gas Drilling and Gross Reserve Addition. Resource and Energy Economics, 17, 261- 279.

Lwayemi, A., 2008. Investment in Electricity Generation and Transmission in Nigeria: Issues and Options. Being a paper presented in the quarter of 2008 in a summit organized by the International Association for Energy Economics, Ibadan, Nigeria.

Mohamed, Z., Bodger, P., 2005. A Comparison of Logistic and Harvey Models for Electricity Consumption in New Zealand. Technological Forecasting and Social Change, 72, 1030-43.

National Bank of Pakistan., 2008. Pakistan's Energy Sector. Economic Bulletin, January-February, 4-15.

NTDC, 2008. Electricity Demand Forecast based on Regression Analysis from 2008 to 2030. National Transmission and Dispatch Company Limited (NTDC), Islamabad, Pakistan.

Okafor, E. O., 2008. Development Crises of the Power Supply and Implications for Industrial sector in Nigeria. Kamala-Raj Journal, 6, 83-92.

Pelesai, A. N., ThankGod, A. O., 2013. The Dynamics of Demand and Supply of Electricity in Nigeria. Developing Country Studies, ISSN 2224-607X (Paper) ISSN 2225-0565 (Online), Vol. 3, No. 3.

Philips, P. C. B., 1986. Understanding Spurious Regressions in Econometrics. Journal of Econometrics, 33(3), 311-340.

Sambo, A. S., 2008. Paper Presented at the "National Workshop on the Participation of State Governments in the Power Sector. Matching Electricity Supply with Demand in Nigeria, Ladi-K. Wali Hall, Sheraton Hotel and Tower, Abuja., International Association for Energy Economics, Fourth Quarter.

The Institute of Strategic Studies (2007b). Energy: Sources of Regional Cooperation and Competition. Conference Proceedings Organized by the Institute of Strategic Studies, Islamabad.

Todaro, M. P., 2000. Economic Development. New York University, 29-62.

Ubi, P. S., Effiom, L., Okon, E. O., 2012. An Econometric Analysis of the Determinants of Electricity of Supply in Nigeria. International Journal of Business Administration, 3. 